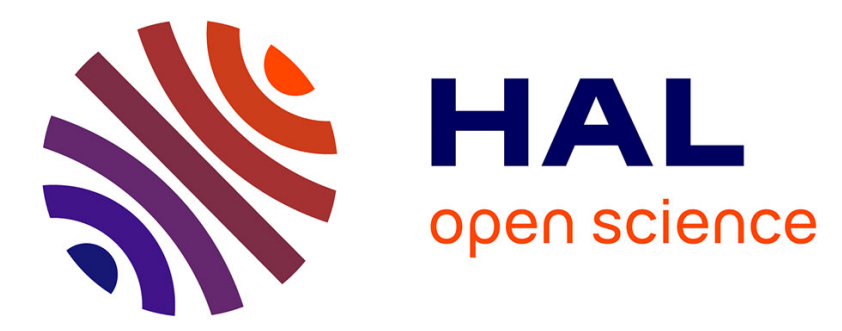

\title{
Genotype and environment: two factors related to autumn cold hardiness on Persian walnut (Juglans regia L.)
}

Mercè Guàrdia, Robert Savé, Raquel Díaz, Antoni Vilanova, Neus Aletà

\section{- To cite this version:}

Mercè Guàrdia, Robert Savé, Raquel Díaz, Antoni Vilanova, Neus Aletà. Genotype and environment: two factors related to autumn cold hardiness on Persian walnut (Juglans regia L.). Annals of Forest Science, 2013, 70 (8), pp.791-800. 10.1007/s13595-013-0328-2 . hal-01201526

\author{
HAL Id: hal-01201526 \\ https://hal.science/hal-01201526
}

Submitted on 17 Sep 2015

HAL is a multi-disciplinary open access archive for the deposit and dissemination of scientific research documents, whether they are published or not. The documents may come from teaching and research institutions in France or abroad, or from public or private research centers.
L'archive ouverte pluridisciplinaire HAL, est destinée au dépôt et à la diffusion de documents scientifiques de niveau recherche, publiés ou non, émanant des établissements d'enseignement et de recherche français ou étrangers, des laboratoires publics ou privés. 


\title{
Genotype and environment: two factors related to autumn cold hardiness on Persian walnut (Juglans regia $\mathbf{L}$.)
}

\author{
Mercè Guàrdia • Robert Savé • Raquel Díaz • \\ Antoni Vilanova $\cdot$ Neus Aletà
}

Received: 4 March 2013 / Accepted: 27 August 2013 /Published online: 3 October 2013

(C) INRA and Springer-Verlag France 2013

\begin{abstract}
- Context J. regia timber is appreciated for high-value wood products. In new plantations, biotic or abiotic events which could affect wood quality should be monitored. Autumn frosts could affect annual shoot development, with consequent loss of timber value or even tree death. In southern Europe, climate change forecasts include erratic and severe autumn frost events.

- Aims The relationship between genotype and environment regarding susceptibility to autumn frost damage was examined in four provenances of Juglans regia L., planted at two ecologically different sites, one subject to Mediterranean and the other Atlantic weather conditions.

- Methods Annual budsticks from eight trees per provenance were collected in November 2010 from each site. The samples were then submitted to freeze-thaw cycles down to $-8,-13$ and $-18{ }^{\circ} \mathrm{C}$, plus a control treatment (keeping samples at
\end{abstract}

Handling Editor: Douglass Jacobs

Contribution of the co-authors Robert Save has contributed with the supervision of the manuscript and with contribution of ideas to improve the text.

Raquel Díaz was directly related on the design of the assay. She contributed on the design of the experimental work and she supervises it, and contributed on improving the manuscript.

Antoni Vilanova has contributed on the design of the assay, on taking field data and improving the final version of the manuscript.

Neus Aletà has contributed with the design of the assay, on writing the paper and improving the text. She has supervised and coordinated both the experimental and writing work.

M. Guàrdia $(\bowtie) \cdot$ R. Savé $\cdot$ A. Vilanova $\cdot N$. Aletà Institut de Recerca i Teconlogia Agroalimentàries (IRTA),

Torre Marimon., 08140 Caldes de Montbui, Spain

e-mail: merce.guardia@irta.cat

R. Díaz

Centro de Investigación Forestal de Lourizán,

36080 Pontevedra, Spain
$5{ }^{\circ} \mathrm{C}$ ). Damage to the stem was assessed using the index of freezing injury calculated from relative electrolyte leakage at each temperature considered. Frost damage to stem, apical and lateral buds was recorded by visual scoring.

- Results Differences in cold acclimation between sites were detected, with provenances exhibiting differences on senescence. A 'provenance $\times$ site' interaction was found in some of the analyses, but the same ranking of susceptibility was detected for all provenances at both sites and in all the tissues analysed. The differences between provenances could be related to their geographical origins, where an altitude gradient was observed.

- Conclusions The genetic component was important in the expression of autumn cold hardiness and, together with productive traits, should be considered in new afforestation projects.

Keywords Frost hardiness - Hardwood species - Adaptive traits $\cdot$ Breeding and selection $\cdot$ Wood production

\section{Introduction}

Woody plants growing in areas of the world with highly seasonable climates must adjust their development and metabolic activity in order to survive seasonal changes. One of these processes is the cold acclimation which corresponds to a sequence of changes in the plant in which each stage opens the way for the next. This starts with growth cessation and is followed by bud set, senescence and dormancy. The last stage gives plants a high level of frost resistance (Sakai and Larcher 1987). Frost tolerance is not a constant property; it is a response to a number of environmental signals which usually precede the arrival of frost: shorter day length and decreases in temperature (Olsen 2010). In order to achieve the hardening required to avoid damage caused by freezing winter 
temperatures, a number of physiological processes take place. These include osmotic adjustment, a decrease in the water content of the stem and buds and/or the storage of starch and proteins (Sauter et al. 1996; Welling et al. 2004; Welling and Palva 2006). The sudden exposure of unhardened trees to subzero temperatures typically results in injury to their shoots, cambium and roots and often leads to the death of the plant. Recent studies have demonstrated that the warming produced by climate change can modify the timing of key phenological events (Way 2011; Savé et al. 2012). This can exacerbate the vulnerability of some species to the first freezing events of autumn. There is some evidence-based information regarding the effects of climate change on freezing periods which reveal a clear increase in climatic variability (IPCC 2007). To avoid frost damage, species have developed adaptive mechanisms during their evolution, resulting in variation in cold hardiness both between species and between genotypes (Sakai and Larcher 1987). Inter-specific variability in frost resistance has been studied in several species of pine (Climent et al. 2009) and Canary laurel (Rodríguez et al. 2005), showing that their ecological niches are related to frost tolerance. This variability also exists at intra-specific level. Some studies have analysed the distribution of populations in several species in order to avoid damage associated with winter freezes. The distributions can display a latitudinal or altitudinal cline, in which environmental factors play an important role, as observed in several species including Betula pendula (Li et al 2003), Acer platanoides L. (Pagter et al. 2010) and some Salix (Li et al. 2005; Ogren 1999).

The use of local provenances in reforestation is a commonly accepted way of ensuring adequate autumn hardening in new plantations. Differences in cold resistance at the population level are often found in tree species that grow in a wide range of environmental conditions, as Juglans regia L. (Fady et al. 2003). This is the only naturally distributed walnut species in Europe and it is highly appreciated for its valuable timber. The optimum growing environment for the Persian walnut is associated with well-watered and warm climatic conditions during the growing season. It requires at least $700 \mathrm{~mm}$ of water supply yearly, which need to be well distributed throughout the year as it cannot withstand summer droughts (Masson 2005). Six months with mean temperatures over $10^{\circ} \mathrm{C}$ will allow suitable growth (Garavel 1959; Masson 2005). The Juglans can display both freezing tolerance through deep supercooling (George et al. 1977) and freezing avoidance through stem shrinking, as observed by Ameglio et al. (2001). These processes can happen when trees are completely cold acclimated, but one of the main limitations, especially in $J$. regia, is sensitivity to out-of-season frost events in autumn or spring (Masson 2005).

The increasing interest in the use of $J$. regia in commercial afforestation in the western Mediterranean has enabled the study of traits specifically related to growth in conjunction with an analysis of adaptive traits (Fady et al. 2003). Variability in both the flushing date and water use efficiency of different progenies of $J$. regia showed that this genetic variation was related to the climate of origin (Aletà et al. 2009). Some differences in cold acclimation were also found in cultivars of $J$. regia that were selected for fruit production (Charrier et al. 2011). Knowledge of genetic differences in resistance to autumn frost in walnut trees from different origins could be of great relevance for future timber production. The damage that a sudden frost event may produce has a notable economic impact. One of the main consequences of this is a reduction in timber quality and even the death of young trees, directly affecting the profitability of the species. Choosing the right materials for each climatic area entails reducing risks of this kind in new plantations.

The main objectives of this work involving $J$. regia were: (1) to compare the level of autumn frost hardiness of four Spanish provenances selected for their wood production and (2) to determine the importance of the provenance and the planting site for autumn frost resistance.

\section{Materials and methods}

\subsection{Plant material and trial sites}

The study was based on Persian walnut seedling trees of four Spanish provenances. These came from different environments on the Iberian Peninsula in which this species grows naturally (Fig. 1). The provenances studied were all from the north of Spain: Valadouro (VL), from the Atlantic coast (northwest of Spain), which is an area with a high number of widely dispersed Persian walnut trees; Pedroso (PD), near the Sierra de la Demanda, on Spain's northern plateau, which corresponds to a traditional walnut production area; Burgohondo (BH), where the walnut population grows on the banks of the Alberche river, in the northern part of the Sierra de Gredos; and La Guingueta (LG), which is located at medium altitude in the Aneu valley of the Pyrenees (Table 1).

Trees were planted in 2001 in two trial sites: one at Reus, near the Mediterranean coast, in the northeast of Spain (TS1), and the other at O'Pino, in the northwest of Spain, which has an Atlantic climate (TS2) (Fig. 1). Both trial sites were planted following identical experimental designs: the four different provenances were distributed in 25 randomized blocks with 8 to 12 trees per origin. Trees were spaced at $3 \times 1.5 \mathrm{~m}$ at TS1, as this was a short-term test, and $3 \times 3 \mathrm{~m}$ at TS2. TS1 was drip irrigated during summer in order to minimise summer drought stress in the Mediterranean area. The extra water applied was approximately $2,500 \mathrm{~m}^{3} \mathrm{ha}^{-1}$ year $^{-1}$. In contrast, TS2 was located in a rainy area (Table 1) where summer irrigation was not necessary. 
Fig. 1 Current leaf fall tree stage on the day of sampling. Frequency of trees at each stage and at each site by provenance (BH, Burgohondo; $L G, \mathrm{La}$ Guingueta; $P D$, Pedroso; $V L$, Valadouro). The frequency goes to $100 \%$ of leaves on tree to $0 \%$
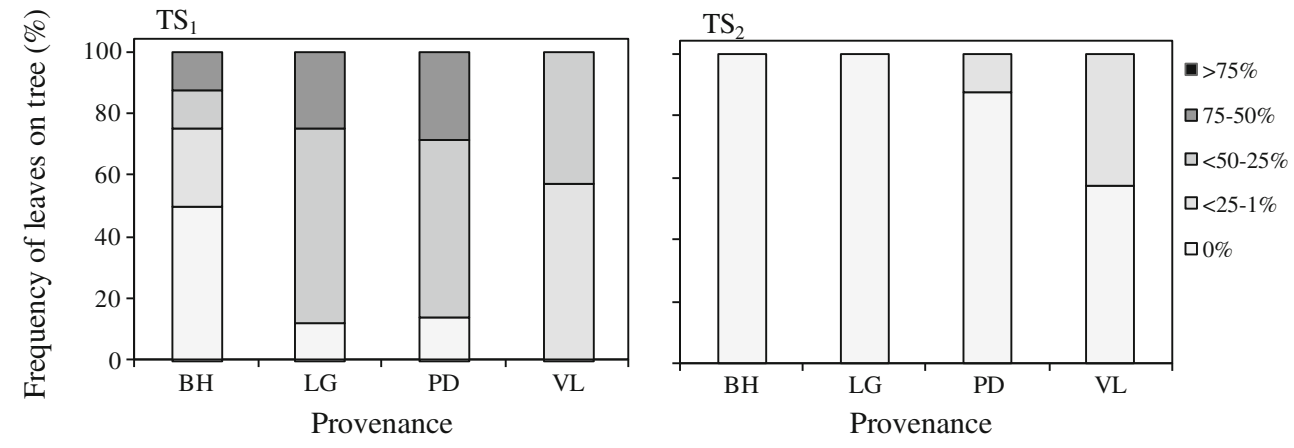

\subsection{Leaf fall assessment, water content and diameter.}

The leaf fall stage of each tree was individually scored during the sample collection (2nd week of November 2010), both in TS1 and TS2. The date was chosen as a probable day of a first freezing event. The scoring system proposed by Díaz and Fernández-López (2005) was used: 5-if the tree had over $75 \%$ of its leaves; 4 -if the tree had between 50 and $75 \%$ of its leaves; 3 -if the tree had between 25 and $50 \%$ of its leaves; 2 -if the tree still had some leaves but fewer than $25 \%$; and 1 -when it had no leaves.

At TS1, two other parameters were registered to obtain detailed information of the provenances: the water content of stems (WC) and tree diameter. To obtain the water content, the fresh weights (FW) of the samples (a piece of $2 \mathrm{~cm}$ of annual budstick) were measured. After a desiccation, the dry weights (DW) were obtained. The water content was calculated as $(\mathrm{FW}-\mathrm{DW}) / \mathrm{DW}$.

The WC evolution was chosen to relate the leaf fall period to a physiological parameter closely linked to the winter acclimation process. This parameter was studied in two distinct provenances (VL and $\mathrm{LG}$ ) in terms of the ecological conditions of their origin (Table 1). One annual apical budstick was removed from 10 trees of each provenance once per week in order to analyse its WC; the leaf fall level was also recorded. The diameter of the tree was measured at breast height (DBH) and this measurement was registered for each of the trees involved in an assay performed at TS1 in the year before the freezing study (on nine year-old trees).

\subsection{Freezing treatments and frost damage assessment}

Four apical budsticks (of $20 \mathrm{~cm}$ long) from eight randomlyselected trees of each provenance were taken to perform frost resistance assays. The samples were collected during the second week of November 2010 at the two trial sites. The budsticks were initially stored at $5{ }^{\circ} \mathrm{C}$ and then immediately sent to the Forest Research Centre of Lourizán in Pontevedra (Galicia). The excised budsticks were moistened with distilled water and then wrapped in cheese cloth and aluminium foil, in groups of eight, in order to prevent desiccation. These packets, containing a sample of each provenance from the two trial sites, were then placed in the freezing chamber. From an initial $5{ }^{\circ} \mathrm{C}$, the temperature inside the chamber was reduced by $2.5^{\circ} \mathrm{C} / \mathrm{h}$ to final temperatures of $-8,-13$ and $-18^{\circ} \mathrm{C}$, respectively, in each cycle. Once the chosen temperature was

Table 1 Geographic references and climatic characteristics of the areas of origin of the four studied provenances and the two trial sites

\begin{tabular}{|c|c|c|c|c|c|c|c|c|c|c|}
\hline $\begin{array}{l}\text { Studied } \\
\text { population }\end{array}$ & Latitude & Longitude & $\begin{array}{l}\text { Altitude } \\
\text { (m) }\end{array}$ & $\mathrm{T} \mathrm{M}\left({ }^{\circ} \mathrm{C}\right)$ & $\begin{array}{l}\text { T MIN } \\
\text { autumn }\left({ }^{\circ} \mathrm{C}\right)\end{array}$ & $\mathrm{P}(\mathrm{mm})$ & RI U & $\begin{array}{l}\text { Fp } \\
\text { (months) }\end{array}$ & $\begin{array}{l}\text { Fs } \\
\text { (months) }\end{array}$ & $\operatorname{Tmin}_{15}\left({ }^{\circ} \mathrm{C}\right)$ \\
\hline $\mathrm{BH}$ & $40^{\circ} 27^{\prime} 12.3^{\prime \prime} \mathrm{N}$ & $4^{\circ} 28^{\prime} 25^{\prime \prime} \mathrm{W}$ & 888 & 14.1 & 7.2 & 584 & 19 & 7.1 & 0.5 & - \\
\hline LG & $42^{\circ} 35^{\prime} 51.42^{\prime \prime} \mathrm{N}$ & $1^{\circ} 8^{\prime} 0.91^{\prime \prime} \mathrm{E}$ & 954 & 8.4 & 4.1 & 763 & 8 & 6.3 & 4.1 & - \\
\hline $\mathrm{PD}$ & $42^{\circ} 18^{\prime} 17.82^{\prime \prime} \mathrm{N}$ & $2^{\circ} 43^{\prime} 42.09^{\prime \prime} \mathrm{W}$ & 780 & 9.5 & 6.8 & 558 & 15 & 7.1 & 3.4 & - \\
\hline VL & $43^{\circ} 33^{\prime} 08^{\prime \prime} \mathrm{N}$ & $7^{\circ} 26^{\prime} 20^{\prime \prime} \mathrm{W}$ & 100 & 13.2 & 8.7 & 1,004 & 3 & 6.1 & 0 & - \\
\hline \multicolumn{11}{|l|}{ Trial site } \\
\hline TS1 & $41^{\circ} 08^{\prime} 59^{\prime \prime} \mathrm{N}$ & $1^{\circ} 10^{\prime} 44^{\prime \prime} \mathrm{E}$ & 71 & 16.8 & 12.5 & 550 & 24 & 5.2 & 0 & 8.2 \\
\hline $\mathrm{TS} 2$ & $42^{\circ} 53^{\prime} 16^{\prime \prime} \mathrm{N}$ & $8^{\circ} 24^{\prime} 39^{\prime \prime} \mathrm{W}$ & 370 & 13.4 & 9.3 & 1,508 & 1 & 6.3 & 0 & 7.6 \\
\hline
\end{tabular}

BH Burgohondo (Ávila); LG La Guingueta (Lleida); PD Pedroso (La Rioja); VL Valadouro (Lugo); TS1 trial site 1 (Tarragona); TS2 trial site 2 (A Coruña); $T M$ mean annual temperature; T MIN autumn mean minimum temperatures during September, October and November; $P$ mean annual accumulated precipitation; RIU Regions for the identification and utilization of reproductive forest material; $F p$ number of months with a probable freezing event; $F_{S}$ number of months with freezing events; $\operatorname{Tmin}_{15}$ average minimum temperatures for the 15 days before sample collection (García del Barrio et al. 2001; Ninyerola et al. 2005). 
reached, it was maintained for $2 \mathrm{~h}$. To obtain a progressive thaw, the temperature inside the chamber was then increased at a rate of $3{ }^{\circ} \mathrm{C} / \mathrm{h}$ until it returned to $5{ }^{\circ} \mathrm{C}$. In the control treatment, the packets of samples were kept at $5{ }^{\circ} \mathrm{C}$. In each freeze/thaw cycle, the temperature was registered and stored in a data logger.

After the thaw, a couple of 1-cm-long pieces were cut from each budstick and the rest of the stick was taken to a greenhouse. The small off-cuts of wood were put into test tubes containing $20 \mathrm{ml}$ of distilled $\mathrm{H}_{2} \mathrm{O}$. These were then stored overnight at room temperature and shaken for $30 \mathrm{~min}$ before the first measurement of the conductivity of the solution $\left(\mathrm{C}_{1}\right)$. To ensure complete electrolyte leakage, the tube-samples were kept in an oven for $90 \mathrm{~min}$ at $80^{\circ} \mathrm{C}$ and then stored overnight at room temperature. After a further $30 \mathrm{~min}$ of shaking, the conductivity of the solution was measured for a second time $\left(\mathrm{C}_{2}\right)$. Relative electrolyte leakage (REL \%) was calculated as: $\mathrm{REL}=\mathrm{C}_{1} / \mathrm{C}_{2} \times 100$; this parameter is widely accepted as a way of measuring frost damage in a number of woody species (Jacobs et al. 2008; Climent et al. 2009; Davarynejad et al. 2009). Considering the REL value of unfrozen samples $\left(\mathrm{REL}_{0}\right)$ according to Flint et al (1967), the Index of sample freezing injury at each temperature $(t)$ was calculated as: $I_{t}=\left(\mathrm{REL}_{t}-\mathrm{REL}_{0}\right) /\left(100-\mathrm{REL}_{0}\right)$. This index ranged from 0 to 1 , from no damage to a completely damaged sample, and has been used efficiently on Juglans spp. (Guàrdia et al. 2013). The sticks which were transferred to the greenhouse were kept at $20{ }^{\circ} \mathrm{C}$ under high relative humidity for 2 weeks. The buds and the internal layer of the bark were then dissected and frost damage was recorded by visual scoring. Bud scoring was made according to the three-point scale described by Díaz et al. (2009) in Castanea sativa Mill.: 0 - if the internal bud is completely green and living; 1 -if the internal tissues are partially brown; and 2-if the tissues are completely brown and the bud is dead. On the other hand, when evaluating internal stem damage, the scoring was established as: 0 - if the tissue was green and there was no damage; 1 - if tissue was green with some light-brown spots; 2 -if tissue was light brown; 3 -if tissue was dark brown; and 4 -if tissue was black and necrotic.

\subsection{Chlorophyll fluorescence}

Measurements of chlorophyll fluorescence were taken to evaluate the initial state of the samples. These were taken from the inner bark of removed budsticks which were used as a control (and stored at $5{ }^{\circ} \mathrm{C}$ ). The sticks were kept in darkness for $30 \mathrm{~min}$ and a piece of stem bark was excised, cutting from the bottom to the top of each budstick. The minimum $\left(F_{0}\right)$ and maximum $\left(F_{\mathrm{M}}\right)$ chlorophyll fluorescence scores were estimated with a Photosynthesis Yield Analyzer (Walz, MINI-PAM), as described in Guàrdia et al. (2013). The $F_{\mathrm{v}}$ parameter was calculated as proposed by Genty et al. (1989): $F_{\mathrm{v}}=F_{\mathrm{m}}-F_{\mathrm{o}}$. The maximum potential PSII efficiency was represented by
$F_{\mathrm{v}} / F_{\mathrm{m}}$, where values of around 0.7 indicated the correct functioning of the photosynthesis system of the plant.

\subsection{Statistical analysis}

A variance analysis (a split-plot assimilated model, in which site was the primary factor and provenance the secondary factor) was applied to the data obtained from the index of freezing injury and from the visual scoring. Four replicates (trees) were selected per provenance and trial site for a total of $(4 \times 4 \times 2) 32$ experimental units. For each experimental unit, four apical budsticks were selected, one for each temperature. The analysis was independently made for each sub-zero temperature, following the model:

$Y_{j k(i)}=\mu+P_{j}+T_{k}+P T_{j k}+T(R)_{k(i)}+\varepsilon_{i j(i)}$

where $Y_{\mathrm{jk}(\mathrm{i})}$ is the value of the response variable measured on the $j$ th provenance on the $i$ th replicate within the $k$ th trial site, $\mu$ is the overall mean, $P_{j}, T_{k}$ and $P T_{j k}$ are the fixed effects of the provenance, the trial site and the interaction between the two, $T(R)_{k(i)}$ is the random effect of the replicate $(n=8)$ within the trial site, and $\varepsilon_{i j(i)}$ is the residue that affects the analysis. Prior to variance analysis, the data relating to visually appreciated damage to the different tissues were transformed by temperature using a normal score transformation, as the traits were categorical and restoration of normality and homogeneity of the variances was required.

When the interaction between trial site and provenance was significant in any of the variables, the analysis was done again separately by trial site only with the fixed effect of the provenance. A Student-Newman-Keuls test was performed to know the differences between provenances at each trial site.

The damage $\left(I_{-18}\right)$ was related with the altitude and with the autumn minimum temperature of the provenance source, using a Pearson correlation.

Analyses were performed with the SAS/STAT software in SAS 9.2.

\section{Results}

\subsection{Evaluation of sample acclimation}

There was a close relationship between the leaf fall stage of the tree and the water content of its annual budsticks; this was quantified by a significant linear regression whose coefficients were $0.89(P<0.0001)$ and $0.77(P<0.0017)$ in $\mathrm{VL}$ and $\mathrm{LG}$, respectively (tested only for TS1).

Leaf senescence at TS1 was not as advanced as at TS2 (Fig. 1). In the case of the Atlantic site, at the time of sampling (15th November), all the BH and LG trees and nearly all of the PD trees were already at stage 1 ( $0 \%$ of leaves on the tree) and 
over $50 \%$ of the VL trees were at this same stage, with the rest being at stage 2 (between 1 and $25 \%$ of leaves on tree). However, at TS1, only the BH provenance had $50 \%$ of trees without leaves.

The photosynthetic efficiency data, expressed by the $F_{\mathrm{v}} / F_{\mathrm{m}}$ parameter and obtained from the inner bark of the control treatment budsticks, also showed significant differences $(P<0.001)$ between the two trial sites. The values were lower for samples from TS2 $\left(F_{\mathrm{v}} / F_{\mathrm{m}}=0.542 \pm 0.01\right)$ than for those from $\operatorname{TS} 1\left(F_{\mathrm{v}} / F_{\mathrm{m}}=0.675 \pm 0.02\right)$ (statistical analysis not shown).

3.2 Frost damage to the stem assessed by the Index of freezing injury

Significant differences were found between the two trial sites and also between different provenances at the sub-zero temperatures analysed (Table 2). As expected, the samples from TS1 were significantly more damaged than those from TS2. The origin of the genotypes seemed to play an increasingly important role as the sub-zero temperature decreased. Observing the results by provenance (Fig. 2a-b), the most damaged trees were those belonging to VL at both of the TSs. Even so, the provenance $\times$ site interaction was significant at $-13{ }^{\circ} \mathrm{C}(P<0.05)$ and an analysis of provenance separated by trial site at this temperature revealed that at TS1 the most damaged provenance was VL, while at TS2 the extent of damage was similar for VL and PD.

\subsection{Visual score of damage to buds and stem}

Visual scoring of stem showed higher damage than the index of freezing injury (Fig. 2). At all the sub-zero temperatures applied, greater damage was observed at TS1 than at TS2 $(P<$ 0.0001) (Fig. 2c-d). There were significant differences among provenances and between sites at -8 and $-13{ }^{\circ} \mathrm{C}$ (Table 3). The provenance $\times$ site interaction was also significant at both temperatures. At $-18{ }^{\circ} \mathrm{C}$, neither provenance nor provenance $\times$ site interaction was significant. As the interaction was significant at -8 and $-13{ }^{\circ} \mathrm{C}$, analyses of variance were done separately for each site. The results obtained showed that

Table 2 Results of ANOVA analysis of damage expressed by the index of freezing injury $\left(I_{t}\right)$ under the three sub-zero temperatures studied

\begin{tabular}{|c|c|c|c|c|c|c|}
\hline \multirow[t]{2}{*}{ Fixed effect } & \multicolumn{2}{|l|}{$I_{-8}$} & \multicolumn{2}{|l|}{$I_{-13}$} & \multicolumn{2}{|l|}{$I_{-18}$} \\
\hline & $F$ & $P$ value & $F$ & $P$ value & $F$ & $P$ value \\
\hline Provenance $(P)$ & 3.85 & 0.0164 & 5.95 & 0.0019 & 10.54 & $<0.0001$ \\
\hline Trial site $(T)$ & 15.98 & 0.0003 & 39.01 & $<0.0001$ & 81.12 & $<0.0001$ \\
\hline$P \times T$ & 2.56 & 0.0687 & 2.90 & 0.046 & 2.19 & 0.1044 \\
\hline
\end{tabular}

Bold $P$ values showed significant differences at TS1, the budsticks from VL were significantly more damaged than those from other provenances at both of the temperatures tested. At TS2, no differences were observed between provenances.

At all the sub-zero temperatures studied, the damages observed on the buds of the trees growing at TS1 were greater, and significantly different, than the effect on the buds of trees at TS2 (Fig. 2e-f, g-h). No differences were observed between different types of bud (apical and lateral) at any of the sub-zero temperatures studied (Table 4 ). The provenance $\times$ site interaction was only significant at $-18{ }^{\circ} \mathrm{C}$, when no differences between provenances were detected at TS1. Only VL was significantly more damaged than the other provenances at TS2 (Figs. 2e-f, g-h). At the temperature of $-8^{\circ} \mathrm{C}$, there were only significant differences relating to the site factor.

\subsection{Relationship between provenance origin and frost damage}

A relevant relationship was found between frost damage at $-18{ }^{\circ} \mathrm{C}$, measured by $I_{t}$ and some ecophysiographic data relating to the environment of the place of provenance (Fig. 3). $I_{-18}$ for the trees was negatively correlated with the altitude of their original growing area: $r=-0.58(P<0.001)$ and $-0.63(P<0.001)$, respectively, for TS1 and TS2 (Fig. 3a). A significant, and in this case positive, correlation was also observed between the $I_{-18}$ and the minimum autumn temperature of their original area, with $r=0.49(P<0.05)$ and $r=0.67$ $(P<0.001)$, respectively, for TS1 and TS2 (Fig. 3b).

\subsection{Relationship between frost damage and growth (DBH)}

The relationship between the damage at temperatures of $-8^{\circ} \mathrm{C}$ $\left(I_{-8}\right)$ and $-18{ }^{\circ} \mathrm{C}\left(I_{-18}\right)$ with breast height diameter $(\mathrm{DBH})$ at TS1, showed no correlation between this two factors. Most of the trees exhibited an $I_{-8}$ below 0.2 and several of them showed no damage at all (values around 0). Some of them had high DBH, where 17 trees had values above the average level of growth for the assay. Considering the extreme subzero temperature assessed $\left(-18^{\circ} \mathrm{C}\right)$, there were still trees with low damage values (around 0.2) and high DBHs, most of them being from LG (data not shown).

\section{Discussion}

In the present study, it has been observed that both factors, planting site and provenance (genotype), have influence on the acquisition of the autumn frost resistance.

4.1 Importance of the planting site on autumn frost resistance

Significant differences in the level of damage by freezing temperatures were found between the two trial sites for all 
Fig. 2 Mean and standard error $(n=8)$ of damage for the four provenances $(B H$, Burgohondo; $L G$, La Guingueta; $P D$, Pedroso; $V L$, Valadouro) at each freezing temperature on trial sites 1 and 2. a-b Damage to the stem expressed by the Index of freezing injury; $\mathbf{c}-\mathbf{d}$ damage to the cambium by visual scoring; $\mathbf{e}-\mathbf{f}$ damage to terminal buds by visual scoring; $\mathbf{g}-\mathbf{h}$ damage to lateral buds by visual scoring. The asterisk shows the significant differences between provenances, analysed separately by trial site when the interaction trial site $\times$ genotype was significant
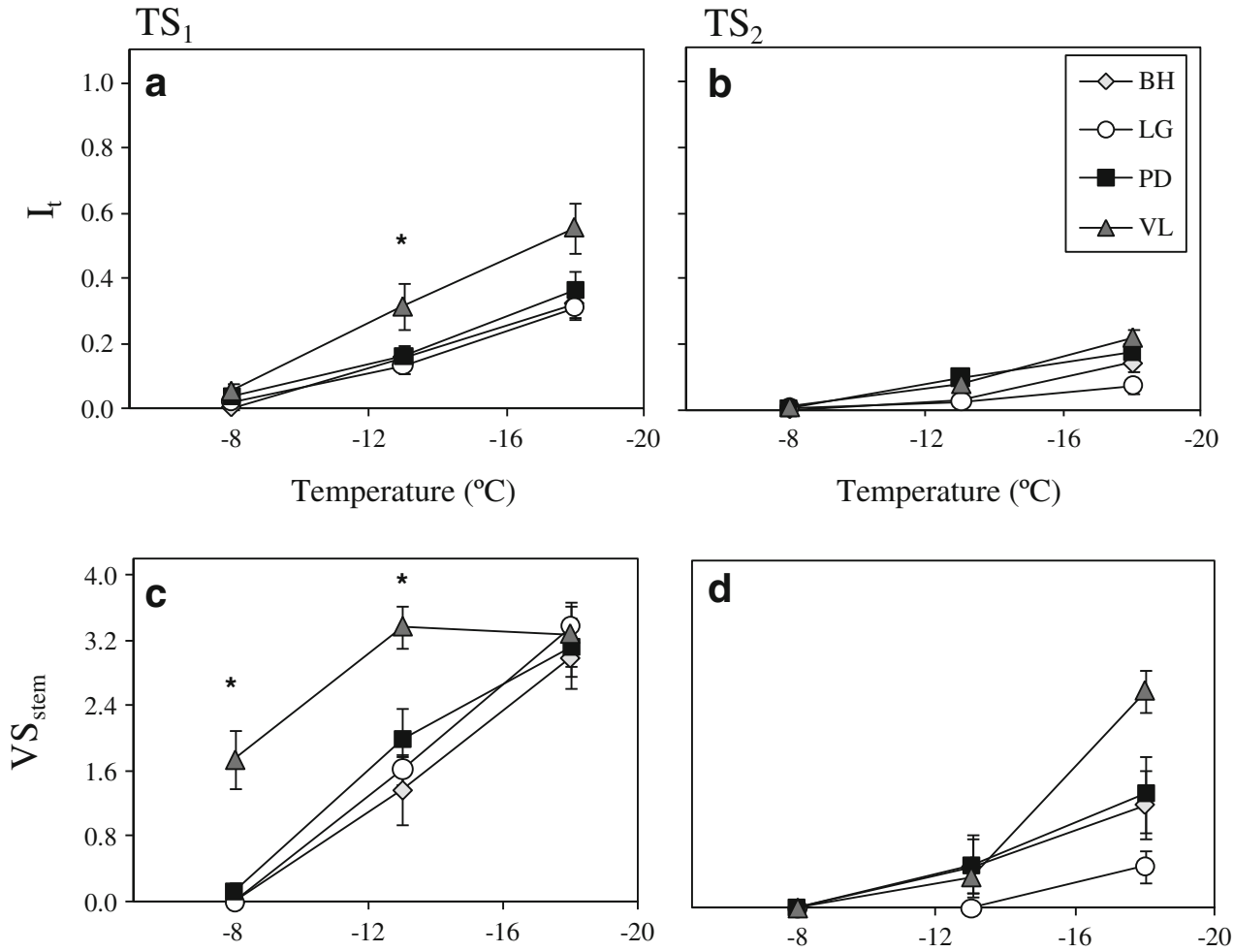

Temperature $\left({ }^{\circ} \mathrm{C}\right)$

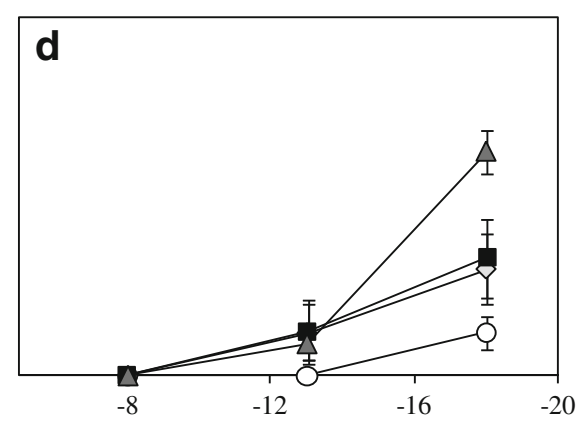

Temperature $\left({ }^{\circ} \mathrm{C}\right)$
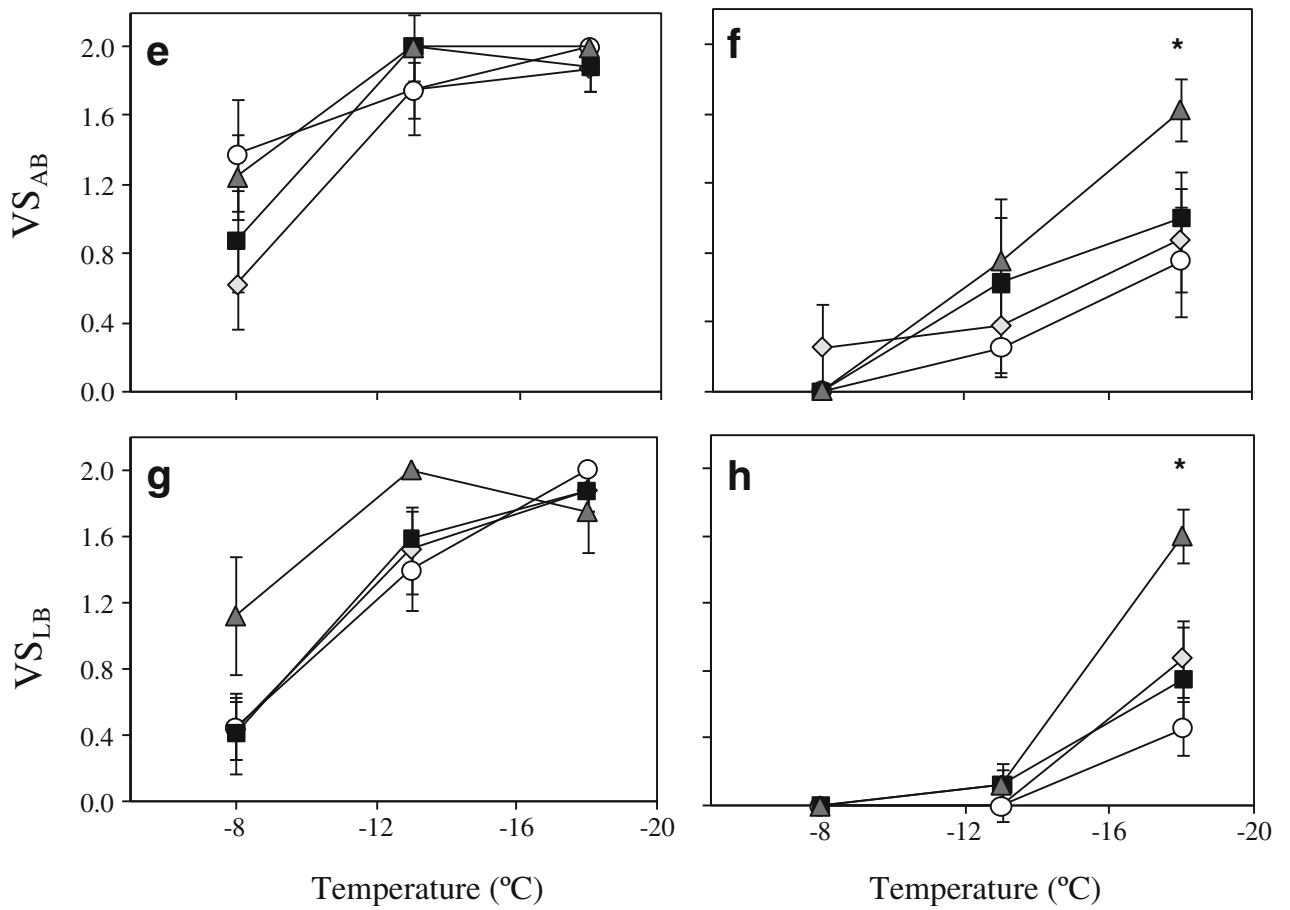

the tissues analysed, with the damage at trial site 1 (TS1) always being greater than at trial site 2 (TS2). These differences could be related to the level of cold hardiness that had already been developed by the time of sample taking at each trial site. The average minimum temperature during the 15 days before the samples were collected was lower at TS2 than at TS1 (Table 1). This temperature was highly related to the acclimation process as demonstrated for $J$. regia (Charrier 
Table 3 Results of ANOVA analysis of damage to the stem, evaluated by visual scoring (VD), under the three sub-zero temperatures studied

Bold $P$ values showed significant differences

\begin{tabular}{|c|c|c|c|c|c|c|}
\hline \multirow[t]{2}{*}{ Fixed effect } & \multicolumn{2}{|c|}{$\mathrm{VS}_{\text {stem }-8}$} & \multicolumn{2}{|c|}{$\mathrm{VS}_{\text {stem-13 }}$} & \multicolumn{2}{|c|}{$\mathrm{VS}_{\text {stem-18 }}$} \\
\hline & $F$ & $P$ value & $F$ & $P$ value & $F$ & $P$ value \\
\hline Provenance $(P)$ & 19.05 & $<\mathbf{0 . 0 0 0 1}$ & 4.65 & 0.0068 & 2.57 & 0.0672 \\
\hline Trial site $(T)$ & 204.47 & $<0.0001$ & 99.51 & $<0.0001$ & 39.24 & $<0.0001$ \\
\hline$P \times T$ & 19.05 & $<0.0001$ & 3.31 & 0.0289 & 2.62 & 0.0635 \\
\hline
\end{tabular}

and Ameglio 2011). The senescence process was more advanced at TS2 where most of trees had no leaves by 15 th November 2010.

The $F_{\mathrm{v}} / F_{\mathrm{m}}$ data obtained from the samples used as a control showed significant differences between the two trial sites (TS1>TS2). A winter drop in $\mathrm{PS}_{\mathrm{II}}$ efficiency was described by Levizou and Manetas (2008) in Prunus cerasus L. and suggested as a possible seasonal adaptive adjustment. More recently, a decrease in $\mathrm{PS}_{\mathrm{II}}$ efficiency has been reported in seedlings of Juglans nigra L. during a simulation of the hardening process (Wilson and Jacobs 2012). The differences between the two trial sites with respect to the $F_{\mathrm{v}} / F_{\mathrm{m}}$ parameter could be related to the level of cold hardiness of the trees from TS2. This development of cold hardiness was more advanced at TS2 compared to the trees planted at TS1 at the time when the samples were collected.

Studies of the ecology of $J$. regia have established that this species has a high demand for water and heat during the growing period if it is to exhibit optimal growth (Masson 2005). The difference in annual rainfall was clearly evident in the results from the two assays; there was three times more rain at TS2 than at TS1, though this was offset by the use of drip irrigation at TS1. However, the optimum average annual temperature at this trial site was above $15^{\circ} \mathrm{C}$ and, from this point of view, TS1 could therefore be a better place for planting walnut trees than TS2 (Garavel 1959) (Table 1). Previous studies at these trial sites showed that, at the fourth growing season, dendrometric data for the two trial sites were very different for the average diameter at breast heigh (DBH), with the higher values being registered at TS1 (Díaz et al. 2006). Moreover, a warm autumn, with minimum temperatures of $12.5^{\circ} \mathrm{C}$, delayed the onset of the senescence period, which was later at TS1 than at TS2 (Díaz et al. 2006). The risk of frost was similar at the two sites (Table 1), but the expected severity of damage to plant tissue was higher on the plantation with a Mediterranean climate than that with an Atlantic influence.

In terms of walnut timber production, it is not known whether Climate Change could impact on the process of hardiness. In the Mediterranean region, summer drought periods could increase in frequency and length (Sheffield and Wood 2008). Walnut is well-known for exhibiting leaf abscission in periods of extreme drought (Ni and Pallardy 1991). If the period of active photosynthesis is too short, as a result of leaf abscission the amount of $\mathrm{C}$ that can be accumulated in autumn may be reduced, which could decrease its winter frost resistance (Gauthier and Jacobs 2011). Despite this fact, some relationship has been found in other species such as Holm oak, where seedlings collected from different areas of the Mediterranean region, showed that the most heat tolerant were also the most freeze tolerant (Gimeno et al. 2009). An in-depth study relating the two stresses (drought and frost) needs to be performed taking into account the provenance regions.

4.2 Importance of the provenances on autumn frost resistance and its relationship with their origin

Observing differences between the four provenances, the 'Valadouro' provenance (VL) was always the most affected by freezing temperatures for each of the tissues tested and at both trial sites. Origin could have an influence on this behaviour: the observed correlations between frost damage and altitude and between frost damage and minimum autumn temperature, which were respectively negative and positive, support this view. Altitude and minimum autumn temperature could be important factors in the development of the
Table 4 Results of ANOVA analysis of damage to buds, evaluated by visual scoring (VD), under the three sub-zero temperatures studied

Bold $P$ values showed significant differences

\begin{tabular}{|c|c|c|c|c|c|c|}
\hline \multirow[t]{2}{*}{ Fixed effect } & \multicolumn{2}{|c|}{$\mathrm{VS}_{\text {buds-8 }}$} & \multicolumn{2}{|c|}{$\mathrm{VS}_{\text {buds }-13}$} & \multicolumn{2}{|c|}{$\mathrm{VS}_{\text {buds }-18}$} \\
\hline & $F$ & $P$ value & $F$ & $P$ value & $F$ & $P$ value \\
\hline Provenance $(P)$ & 1.15 & 0.3327 & 2.93 & 0.0374 & 4.18 & 0.0079 \\
\hline Trial site $(T)$ & 57.25 & $<0.0001$ & 123.18 & $<\mathbf{0 . 0 0 0 1}$ & 61.38 & $<\mathbf{0 . 0 0 0 1}$ \\
\hline$P \times T$ & 2.08 & 0.1081 & 0.07 & 0.9775 & 5.68 & 0.0012 \\
\hline Type of bud & 0.01 & 0.9297 & 0.00 & 1.000 & 0.00 & 1.000 \\
\hline
\end{tabular}




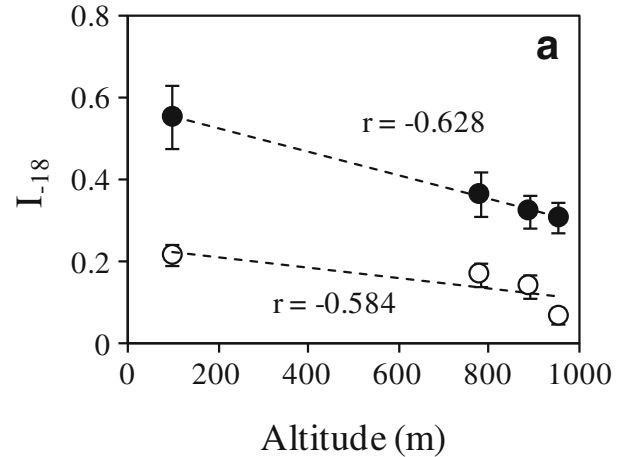

Fig. 3 Correlation between the Index of freezing injury at $-18^{\circ} \mathrm{C}$ and $\mathbf{a}$ the altitude of the origin of the populations, $\mathbf{b}$ the mean minimum temperatures during September, October and November of the original

hardening process of the chosen provenances, at their site of origin. The observed variability in frost damage followed an elevation gradient. The 'La Guingueta' provenance (LG) from the 954-m high Pyrenean valley with the lowest autumn temperature displayed the least frost damage. In addition, $\mathrm{VL}$ - which was located only $100 \mathrm{~m}$ above sea level and had the highest autumn temperature and zero probability of an autumn frost-event - was the provenance that exhibited most frost damage. PD and $\mathrm{BH}$ were more similar to $\mathrm{LG}$ than to $\mathrm{VL}$, as expected. This is common behaviour in other species such as Pinus sylvestris L. (Persson et al. 2010), Picea abies L. Karst (Kathke and Bruelheide 2011), and even in some deciduous species of the genus Fagus, Quercus (Vitasse et al. 2011) and Castanea sativa Mill., in which autumn bud damage to different populations has been related to low temperatures of their places of origin (Díaz et al. 2009). This would confer great importance to provenance (genotype) in the process of cold acclimation and resistance to autumn frost damage. However, the adaptive character of frost resistance should also be considered with respect to other specific traits related to timber production, such as growth rate and forest growth habit. In this sense, the results of previous studies involving dendrometric characterization of the first four growing seasons of provenances at the two trial sites (Díaz et al. 2006) reveal genetic differences, with VL being the most vigorous provenance. Focusing on TS1, where the highest growth was observed, the two characters (growth and frost resistance) seemed not to be related. At $-8{ }^{\circ} \mathrm{C}$, it was observed that materials from the four provenances which were either less or not affected by sub-zero temperatures and which had high diameter at breast height (DBH) values. This suggests that breeding selection should be directed to individuals (family genitors). When applying extreme freezing temperatures, provenances such as VL showed frost sensitiveness and high DBH. However, for other provenances such as LG some of the trees showed DBH around the average of all the samples and they were also tolerant to autumn frost. This shows that autumn frost resistance and a good growth

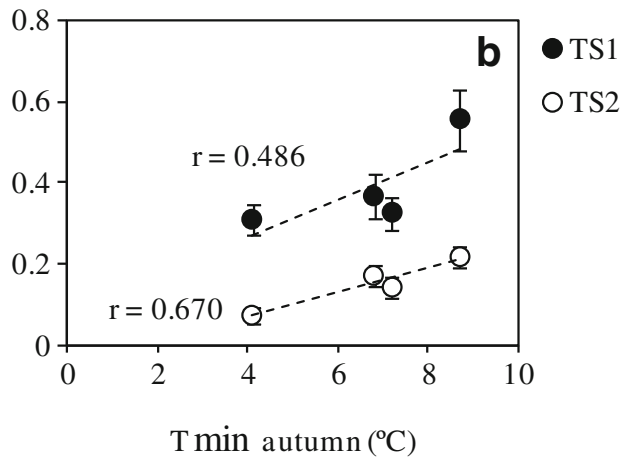

locations of the populations. Each point corresponds to eight trees of the same provenance. In each figure, a correlation was made for the two trial sites (TS1 and TS2)

ratio are not mutually exclusive. This observed behaviour supports that extreme climatic events can influence on longterm survival.

The main objective of breeding programmes in broadleaf species is to obtain a high growth ratio and thus optimize the use of the natural resources available at each planting site. Adaptive characters are becoming increasingly important in this respect. In $J$. regia, genetic differences have been found in traits such as water use efficiency (Fady et al. 2003; Aletà et al. 2009).

\section{Conclusions}

The findings of this work point to differences in behaviour with respect to autumn frost resistance within $J$. regia origins. At trial site 1, localized in the north east of Spain, the first freezing damage was observed by visual scoring at $-8{ }^{\circ} \mathrm{C}$. This situation should be carefully considered in afforestation with J.regia for timber production in the Mediterranean area.

Reforestation with local provenances or with trees from places with comparable environments is the usual choice of farmers/foresters looking to minimize damage from autumn frosts. Specific material selected for adaptive traits do not exist in the market. Farmers require trees selected for both adaptive and productive features in order to optimize their revenue, in each environment. Seedlings should therefore come from tested clonal seed orchards, or even better from selected family genitors; this should guarantee homogeneity and adaptability of reproductive forest material to the target environment of new afforestations (Aletà and Vilanova 2011).

Acknowledgements We would like to thank Eva Prada for her help with the experimental work.

Funding This work was supported by two INIA projects (RTA 200500057-C05-00 and RTA 2010-00104-00-00), a MICIN project (CSC2008-00040_CONSOLIDER MONTES) and also by an FPI-INIA $\mathrm{PhD}$ grant to Mercè Guàrdia. 


\section{References}

Aletà N and Vilanova A (2011) Criterios orientadores para la admisión de materiales de base del géreno Juglans, Ministerio de Medio Ambiente y Medio rural y Marino, Madrid

Aletà N, Vilanova A, Díaz R, Voltas J (2009) Genetic variation for carbon isotope composition in Juglans regia L.: relationships with growth, phenology and climate of origin. Ann For Sci 66:413-424

Améglio T, Cochard H, Ewers FW (2001) Stem diameter variations and cold hardiness in walnut trees. J Exp Bot 52:2135-2142

Charrier G, Ameglio T (2011) The timing of leaf fall affects cold acclimation by interactions with air temperature through water and carbohydrate contents. Environ Exp Bot 72:351357

Charrier G, Bonhome M, Lacionte A, Améglio T (2011) Are bud burst dates, dormancy and cold acclimation in walnut trees (Juglans regia L.) under mainly genotypic or environmental control? Int J Biometeorol 55:763-774

Climent J, Silva FCE, Chambel MR, Pardos M, Almeida MH (2009) Freezing injury in primary and secondary needles of Mediterranean pine species of contrasting ecological niches. Ann For Sci 66:407415

Davarynejad G, Aryanpooya Z, Fahadan A, Davarynejad E (2009) Evaluation of susceptibility of walnut genotypes to sudden cold and frost injury. Hort Environ Biotechnol 50:497-501

Díaz R, Fernández-López J (2005) Genetic variation at early ages for several traits of interest for timber-production breeding of Juglans regia. Can J Forest Res 35:235-243

Díaz R, Baoune N, Ninot A, Fernandez-Lopez J, Aletà N (2006) Performance differences and genetic parameters of four local Spanish populations of Juglans regia in the north of Spain. Acta Hortic 705:103-108

Díaz R, Johnsen O, Fernández-López J (2009) Variation in spring and autumn freezing resistance among and within Spanish wild populations of Castanea sativa. Ann For Sci 66:708-712

Fady B, Ducci F, Aletà N, Becquey J, Vázquez RD, López FF, JayAllemand C, Lefevre F, Ninot A, Panetsos K, Paris P, Pisanelli A, Rumpf H (2003) Walnut demonstrates strong genetic variability for adaptive and wood quality traits in a network of juvenile field tests across Europe. New Forest 25:211-225

Flint HL, Boyce BR, Beattie DJ (1967) Index of injury-a useful expression of freezing injury to plant tissues as determined by electrolytic method. Can J Plant Sci 47:229-230

Garavel L (1959) Le culture du noyer. J.B. Baillière et fils, Paris

García del Barrio JM, de Miguel J, Alía R, Iglesias S (eds) (2001) Regiones de Identificación y Utilización de Material Forestal de Reproducción. Ministerio de Medio Ambiente, Serie Cartográfica

Gauthier M-M, Jacobs DF (2011) Walnut (Juglans spp.) ecophysiology in response to environmental stresses and potential acclimation to climate change. Ann For Sci 68:1277-1290. doi:10.1007/s13595011-0135-6

Genty B, Briantais JM, Baker NR (1989) The relationship between the quantum yield of photosynthetic electron-transport and quenching of chlorophyll fluorescence. BBA-Gen Subjects 990:87-92

George MF, Hong SG, Burke MJ (1977) Cold hardiness and deep supercooling of hardwoods - it's occurrence in provenance collections of red oak, yellow birch, black walnut and black cherry. Ecology 58:674-680

Gimeno TE, Pias B, Lemos-Filho JP, Valladares F (2009) Plasticity and stress tolerance override local adaptation in the responses of Mediterranean holm oak seedlings to drought and cold. Tree Physiol 29:87-98. doi:10.1093/treephys/tpn007

Guàrdia M, Díaz R, Savé R and Aletà N (2013) Autumn frost resistance on several walnut species: methods comparison and impact of leaf fall. Forest Sci (in press)
IPCC (2007) Climate Change 2007: the physical science basis. Contribution of Working Group I to the Fourth Assessment Report of the Intergovernmental Panel on Climate Change. Cambridge University, Cambridge, p 996

Jacobs DF, Willson CJ, Ross-Davis AL, Davis AS (2008) Cold hardiness and transplant response of Juglans nigra seedlings subjected to alternative storage regimes. Ann For Sci 65:606

Kathke S, Bruelheide H (2011) Differences in frost hardiness of two Norway spruce morphotypes growing at Mt. Brocken, Germany. Flora 206:120-126

Levizou E, Manetas Y (2008) Maximum and effective PSII yields in the cortex of the main stem of young Prunus cerasus trees: effects of seasons and exposure. Trees-Struct Funct 22:159-164

Li CY, Junttila O, Heino P, Palva ET (2003) Different responses of northern and southern ecotypes of Betula pendula to exogenous ABA application. Tree Physiol 23:481-487

Li C, Wu N, Liu S (2005) Development of freezing tolerance in different altitudinal ecotypes of Salix paraplesia. Biol Plantarum 49:65-71

Masson G (2005) Autoécologie des essences forestières-Comment installer chaque essence à sa place, Lavoisier.

Ni BR, Pallardy SG (1991) Response of gas-exchange to water-stress in seedlings of woody angiosperms. Tree Physiol 8:1-9

Ninyerola M, Pons X and Roure JM (2005) Atlas Climático Digital de la Península Ibérica. Metodología y aplicaciones en bioclimatología y geobotánica. ISBN 932860-8-7. Universidad Autónoma de Barcelona, Bellaterra

Ogren E (1999) Fall frost resistance in willows used for biomass production. I. Characterization of seasonal and genetic variation. Tree Physiol 19:749-754

Olsen JE (2010) Light and temperature sensing and signaling in induction of bud dormancy in woody plants. Plant Mol Biol 73:37-47

Pagter M, Kristoffersen A, Bronnum P, Jensen M (2010) Phenotypic differences in development of cold hardiness in three latitudinal populations of Acer platanoides L. Scand J Forest Res 25: $412-420$

Persson T, Andresson B, Ericsson T (2010) Relationship between autumn cold hardiness and field performance in northern Pinus sylvestris. Silva Fenn 44:255-266

Rodriguez AMG, Jimenez MS, Morales D (2005) Seasonal and intraspecific variation of frost tolerance in leaves of three Canarian laurel forest tree species. Ann For Sci 62:423-428. doi:10.1051/ forest:20050138

Sakai A and Larcher W (1987) Frost survival of plants. Responses and adaptation to freezing stress, Springer-Verlag. Ecological series 62 , Berlin Germany, $321 \mathrm{p}$

Sauter JJ, Wisniewski M, Witt W (1996) Interrelationships between ultrastructure, sugar levels, and frost hardiness of ray parenchyma cells during frost acclimation and deacclimation in poplar (Populus $\times$ canadensis Moench robusta) wood. J Plant Physiol 149:451-461

Savé R, de Herralde F, Aranda X, Pascual D, Funes I, Biel C (2012) Potential changes in irrigation requirements and phenology of maize, apple trees and alfalfa under global change conditions in Fluvià watershed during XXIst century: results from a modelling approximation to watershed, level water balance. Agr Water Manage 114:78-87

Sheffield J, Wood EF (2008) Projected changes in drought occurrence under future global warming from multi-model, multi-scenario, IPCC AR4 simulations. Clim Dynam 31:79-105. doi:10.1007/ s00382-007-0340-z

Vitasse Y, Francois C, Delpierre N, Dufrene E, Kremer A, Chuine I, Delzon S (2011) Assessing the effects of climate change on the phenology of European temperate trees. Agr Forest Meteorol 151: 969-980

Way DA (2011) Tree phenology responses to warming: spring forward, fall back? Tree Physiol 31:469-471 
Welling A, Palva ET (2006) Molecular control of cold acclimation in trees. Physiol Plantarum 127:167-181

Welling A, Rinne P, Vihera-Aarnio A, Kontunen-Soppela S, Heino P, Palva ET (2004) Photoperiod and temperature differentially regulate the expression of two dehydrin genes during overwintering of birch (Betula pubescens Ehrh.). J Exp Bot $55: 507-516$

Wilson BC, Jacobs DF (2012) Chlorophyll fluorescence of stem cambial tissue reflects dormancy development in Juglans nigra seedlings. New Forest 43:771-778 